\title{
ТРУДНЫЕ ВОПРОСЫ СОВРЕМЕННОГО РАЗВИТИЯ
}

\section{А.В. Журавский}

Журавский Александр Владимирович, руководитель Центра этноконфессиональных и политических исследований РАГС.

Международный общественный фонд социально-экономических и политических исследований (Горбачев-Фонд) выпустил в свет фундаментальное исследование “Грани глобализации. Трудные вопросы современного развития” [1]. Эта книга, созданная представительным авторским коллективом под руководством экс-президента СССР М.Горбачева, — редкий случай того, когда коллективность труда выступает его несомненным достоинством. “Грани глобализации” отражены не только в своей многоаспектности, но и в различных авторских подходах к проблеме. При этом монография не создает впечатления распадающейся. В ней нет непреодолимого конфликта или столкновения авторских интерпретаций: масштаб и сложность темы оставляет место для сосуществования разных исследовательских дискурсов.

Уже в предисловии М.Горбачев формулирует концептуальный подход авторского коллектива к исследованию проблем глобализации: следует различать глобализацию как объективное явление, обусловленное экономическими, научно-техническими процессами, и политику неолиберального глобализма, сущность которой — “в навязывании остальному миру рыночной либерализации и дерегулирования во имя 'равных' условий свободного движения капиталов, товаров и услуг по всему миру, устранении национальных барьеров” (с.13). По мнению авторов книги, в условиях асимметричности и поляризованности мировой политической и экономической систем неолиберальный глобализм лишь закрепляет разделение мира на доминирующий Центр и зависимую периферию. Неолиберальная глобализация становится катализатором социально-политической напряженности и конфликтов в “мировой деревне”, ведет к росту глобальной и региональной конфликтогенности: этнического и религиозного экстремизма, ксенофобии, терроризма.

Вместе с тем, по оценке Горбачева, “политика неолиберального глобализма... переживает глубокий кризис, выход из него видится в серьезном переосмыслении мировых реалий, изменении господствующей системы ценностей, мотивов, приоритетов. Более справедливый и демократический мировой порядок требует нового международного консенсуса, основанного на социальных ценностях" (с.18). В подтверждение реальности подобной перспективы он ссылается на инициативу В.Путина, предложившего на одном из саммитов “восьмерки” модель “социально ответственной глобализации”. Очевидно, что такая модель невозможна без институциональных и ценностных изменений в характере мирового порядка: глобальные проблемы должны способствовать формированию глобальной ответственности. Так возникает идея “глобализации с человеческим лицом” как нового политического устройства мира, которое будет строиться не на господстве одной или нескольких держав, а на принципах сотрудничества и солидарности.

Несмотря на кажущуюся утопичность подобной модели все дальнейшие размышления авторов исследования свидетельствуют о ее безальтернативности.

перваЯ Часть монографии посвящена осмыслению социальных, феноменологических, экономических, политических аспектов глобализации, а также критическому анализу доминирующих на Западе подходов и оценок.

В главе “Глобальность: новое измерение человеческого бытия” В.Кувалдин обращает внимание на то, что, хотя корни глобализационных процессов уходят в глубь веков, сама глобализация - феномен XX в. Ее идейный фундамент — попытка выработать общее для жителей Земли понимание ключевых принципов жизнеустройства, создать глобальное мегаобщество как альтернативу доминировавшей на протяжении Нового времени (эпохи Модерна) модели национального государства. Все это ведет к появлению ряда 
гносеологических и инструментальных проблем, которые, по мнению исследователя, на данном этапе неразрешимы.

Очевидно, что глобализация подрывает “островное сознание”: в современном мире нельзя изолироваться от глобальных проблем. Если мир взаимозависим, значит он — взаимоуязвим. Различные проекты модернизации политических систем вступают в конфликт с идеей устойчивого развития и управляемости, что порождает глобальные системные деструкции.

В научной рефлексии Кувалдина больше вопросов, чем ответов, больше наблюдений, чем модельных построений. Обращаясь к прошлому, он описывает ХХ в. как “грандиозную сшибку различных глобализационных проектов - колониального, фашистского, коммунистического, либерального, фундаменталистского”. Либеральный проект оказался наиболее жизнеспособным, однако у либерализма есть свои слабости и изъяны, “не позволяющие ему стать конституирующей основой глобального мира”. По оценке Кувалдина, холодная война представляла собой не только “смертельно опасное геополитическое соперничество двух сверхдержав, но и особую форму кондоминиума, обеспечивавшую управляемость мировым развитием в условиях быстрой модернизации” (с. 41). С утратой биполярности мировая система превратилась в заложницу неолиберального подхода к решению проблем экономической и политической модернизации. В результате, открыв для вырвавшегося вперед Запада уникальные возможности, глобализация поставила отставший Юг перед выбором между зависимостью и изоляцией (с. 42).

“Ахиллесовой пятой” глобализации исследователь считает политические институты, указывая, что средства контроля, координации, управления, которые веками создавались на национальном уровне, явно утрачивают эффективность в глобализирующемся мире (с. 45). Но у мегаобщества, отмечает он, имеется свой фундамент — новая глобальная экономика. Первоначально ключевыми агентами глобализации, расчищавшими путь свободному предпринимательству, выступали правительства ведущих западных государств, а также такие международные структуры, как МВФ, ВБ и ВТО. Волна трансграничных слияний и приобретений превратила в глобальных игроков и транснациональные корпорации (ТНК), играющие в современной экономике системообразующую роль. В ТНК глобальная экономика обретает свою институциональную форму.

Вместе с тем обнаружилась и “родовая травма” мегаобщества — резкие социальные контрасты, конфликтность. Глобализация влечет за собой глубокую трансформацию всей системы социальных связей индивида, ставит его перед проблемой внутреннего самоопределения, предполагая появление глобальной идентичности “граждан мира” (с.76). Насколько трудно идут процессы формирования глобального сознания, можно судить по тем проблемам, которые возникли в последние годы в Европейском Союзе.

Проанализировав значение государственного суверенитета в современном миропорядке, Кувалдин приходит к неожиданному заключению: создание наднациональных институтов и региональная интеграция придают государству второе дыхание. Региональная интеграция не ослабила стремление шотландцев, фламандцев, басков, французов Квебека обрести свою государственность, да и национальные правительства стран членов ЕС не спешат передавать полномочия брюссельской бюрократии (с.77). Называя государство “несокрушимым Левиафаном”, Кувалдин высказывает убеждение в том, что национальные государства пока преждевременно списывать со счета. Утратив былую монополию в сфере международных отношений, они остаются ключевыми игроками на поле мировой политики.

Основной вывод Кувалдина таков: рождающееся мегаобщество сшито на живую нитку, как лоскутное одеяло; мы находимся в начальной стадии длительного процесса преобразований, что затрудняет оценки и прогнозы.

Глава “Экономическая глобализация и кризис мирового хозяйственного порядка”, написанная академиками О.Богомоловым и А.Некипеловым, фокусирует внимание на “экономической глобализации”, реальность которой мир оценил после нефтяного кризиса 1973 г., а также стагфляции 1980-х годов.

В мировой экономике, отмечают исследователи, складывается другая система цен и финансовых отношений, нежели на внутренних рынках. Глобальная экономика имеет особую денежную систему со своими институтами, и для большинства стран мира международные расчеты связаны с конвертацией национальной валюты в международную. Глобализация приводит к интернационализации национального производства: для целого ряда стран мировой рынок становится необходимым условием функционирования народного 
хозяйства. Его роль в развитии реального сектора экономики оказывается сопоставима с ролью внутреннего рынка. Это уже новое качество интернациональной взаимозависимости и кооперации, позволяющее говорить о глобальной экономике как особом феномене современной истории (с.108). Переливающиеся из страны в страну потоки товаров и услуг, капиталов и людей, глобальные системы коммуникаций и информации, деятельность международных экономических и финансовых организаций и корпораций образуют ткань глобальной экономики, в которую в большей или меньшей степени вплетаются все без исключения национальные экономики (с.105).

Один из признаков наступления эры экономического глобализма Богомолов и Некипелов видят в беспрецедентной транснационализации производства, торговой и банковской деятельности. Считая ТНК главной движущей силой процесса экономической глобализации, они указывают, что экспансия последних обостряет противоречия между национальной и глобальной экономикой.

Свидетельством перехода к глобализму является, по мнению исследователей, и то обстоятельство, что глобальное измерение приобретают не только экономические связи, но и многие экономические проблемы, которые уже не поддаются решению силами отдельных стран. Сравнительно новым структурным элементом глобальной экономики представляются им региональные интеграционные группировки, выступающие одновременно и как проявление более широкого процесса глобализации, и как инструмент защиты от ее неблагоприятных последствий (с.113).

В главе убедительно продемонстрирована противоречивость последствий экономической глобализации, выгоды от которой распределяются неравномерно и в глазах многих стран - несправедливо.

Америкоцентричность такой глобализации очевидна: в долларах совершаются до 60\% всех торговых сделок на международных рынках; на американскую валюту приходится примерно 60\% официальных валютных резервов стран мира. На привилегированное положение ведущих индустриальных держав в мировой экономике указывает и “утечка мозгов” из менее развитых стран

Высокая степень экономической взаимозависимости стран, гигантские нерегулируемые потоки “горячих” спекулятивных капиталов сделали глобальную экономику уязвимой. Достаточно сказать, что общий дневной объем торговли валютой на международных биржах значительно превосходит совокупные резервы центральных банков стран “семерки”. В таких условиях правительства и центральные банки не в состоянии обеспечить стабильность своих валютных курсов при помощи интервенций и должны при решении этой задачи полагаться главным образом на психологические факторы.

Возникают и новые вызовы национальному суверенитету. Согласно прогнозу авторов, XXI в. станет веком противоборства национальной бюрократии и международных экономических институтов — ТНК и других структур, не имеющих национальной “прописки”. Одновременно национальные государства будут испытывать проблемы, связанные с массовой миграцией рабочей силы из бедных и политически нестабильных стран мира (с. 123). Существует реальная угроза, что вместо “железного занавеса”, разделявшего в прошлом Восток и Запад, опустится иной занавес — между Севером и Югом, — препятствующий переселению людей.

Глобализация снижает эффективность макроэкономической политики государств. Национальным правительствам становится все сложнее собирать налоги и финансировать “государство благосостояния”, контролировать инфляцию и валютный курс.

В контексте проблем экономической глобализации авторы оценивают и антиглобализм. По их мнению, данный феномен представляет собой не отрицание объективного процесса мирового развития, а протест против его современных форм, отражающих интересы ведущих индустриальных держав, прежде всего США, и не учитывающих в должной мере проблем и трудностей остального мира (с. 126).

Критикуя идеологию Вашингтонского консенсуса, Богомолов и Некипелов обращают внимание на инициативу бывшего первого вице-президента ВБ Дж.Стиглица, сформулировавшего более разумные и справедливые принципы организации мирового сообщества (так наз. “поствашингтонский консенсус”). Они согласны с западным экономистом в том, что “главное - это не либерализация и дерегулирование, а создание механизма регулирования, обеспечивающего эффективную работу финансовой системы”, и манифестируют его устами собственное позитивное отношение к установкам и подходам “поствашингтонского консенсуса”: “Люди стремятся к устойчивому развитию, включающему сохранение 
природных ресурсов и обеспечение здоровой окружающей среды. Люди стремятся к равноправию, когда все, а не только привилегированные группы пользуются плодами общественного прогресса. Люди стремятся к развитию демократии, при которой граждане... участвуют в принятии решений, оказывающих влияние на их жизнь” (с. 142).

Согласно заключению исследователей, сегодня уже отчетливо ощущается потребность в смене парадигмы развития экономической глобализации: господствующие ныне неолиберальные концепции должны уступить место иным, допускающим сочетание рынка с дирижизмом и требующим укрепления демократических начал в международных отношениях, что, в свою очередь, предполагает реформирование главных международных экономических и финансовых организаций. Определенные шаги в данном направлении уже сделаны, полагают они, ссылаясь на создание в рамках ООН Совета экономической безопасности, а также Мирового центрального банка и других аналогичных организаций.

В главе “Западные концепции экономической глобализации” В.Коллонтай анализирует различные трактовки механизмов глобализации, ее методов, темпов и последствий; меняющейся хозяйственной роли национальных государств; перспектив и проблем формирования глобального рынка, его отличий от национального; становления новых центров принятия решений в мировом хозяйстве и возможностей управления мировыми процессами.

Критика неолиберальной глобализации, отмечает автор, исходит не только из развивающихся стран и имеет не только марксистские, неокоммунистические и социал-демократические корни. Заметный вклад в ее развитие внесли такие западные ученые, как М.Грановетер, М.Кастельс, Р.Сведберг, А.Сен, А.Турен, Р.Холлингсворт, Ф.Шмиттер, В.Штрек, А.Этциони, по-новому поставившие вопрос о неразрывной связи экономики с другими сферами общественной жизни, об обусловленности экономических процессов совокупностью институтов, сложившихся в обществе.

К числу влиятельных критиков неолиберальной модели глобализации относится, в частности, так наз. школа “международной политической экономии”, получившая наибольшее распространение в англосаксонских странах. Ее представители (С.Стрендж, Э.Хеллайнер, Р.Андерхилл и др.) одними из первых развернули конкретные исследования механизмов глобализации, сосредоточившись на анализе взаимодействия внешней политики и мирохозяйственных процессов. За обуздание экономики, особенно в ее неолиберальном, глобализационном варианте, активно выступают также современные эконом-экологи (П.Эйкинс, Х.Хендерсон, Г.Дейли и т.д.). Подчеркивая ограниченность природных ресурсов и восстановительной способности природы, они настаивают на кардинальном пересмотре экономических подходов и указывают на необходимость более полного учета взаимодействия окружающей среды (социальной и природной) и хозяйственной сферы.

В последнее время происходит быстрое сближение различных направлений критики неолиберальной глобализации. Под их влиянием складывается совершенно иной образ рынка (в т.ч. и глобального), нежели рисуют неолибералы. Становится все очевиднее, что наряду с чисто формализованными рыночными отношениями на взаимодействия хозяйственных субъектов огромное влияние оказывают неформальные, неэкономические обстоятельства, социокультурная среда, морально-этический климат в обществе и т.д. (с. 157). Рынок предстает не как самодовлеющий фактор, способный решить все проблемы, а как один из общественных механизмов, зависящий от социально-политической сферы, от исторического и культурного наследия общества.

Конец 1990-х годов был отмечен резкой активизацией дискуссий вокруг глобализации. В исследованиях известных социологов, политологов и экономистов (Дж.Бхагвати, Дж.Стиглица, Дж.Сакса, П.Кругмана и др.) были вскрыты опасности, связанные с безусловной ориентацией на ценности Вашингтонского консенсуса. Пересмотрела свои экономические взгляды и часть неолибералов. Так, известный британский консерватор Дж.Грэй выпустил в 1998 г. книгу, где указал на принципиальную несовместимость свободного рынка и демократии, на разнонаправленность развития и усиление различий между странами в результате осуществления неолиберальной экономической политики.

Коллонтай явно сочувственно относится к критике неолиберальной глобализации, расщепляющей национально-хозяйственные комплексы и способствующей формированию экспортно-ориентированной модели развития с минимумом социального перераспределения, ущербным внутренним рынком и растущим числом неэффективных секторов. Такая модель развития приводит к резкой имущественной 
дифференциации общества и маргинализации все большей части населения (с. 167). Согласен он и с теми западными учеными, которые пишут о недопустимости механического перенесения законов регулирования национальных рынков на глобальную мирохозяйственную систему.

В связи с кризисами 1990-х годов в западной экономической и политологической науках началось обсуждение возможностей управления процессами глобализации, развернулся поиск “новых парадигм”. На складывающиеся сегодня концепции немалое влияние оказывают иерархические подходы, отталкивающиеся от опыта формирования национально-государственных систем. Таковы теории, отождествляющие управляемость международных отношений с наличием страны-гегемона, устанавливающей “правила игры” на мировой арене (и обеспечивающей их соблюдение).

Широкое распространение получило также представление о том, что наиболее подходящим инструментом управления мировым сообществом и мировым хозяйством являются ведущие международные организации как прообраз будущего глобального правительства. Однако финансовый кризис 1997 - 1999 гг. поставил под сомнение правильность политики таких важнейших международных экономических организаций, как МВФ и ВТО. В демократических кругах нарастает неприятие международно-бюрократических подходов, усиливающих разрыв между управляющей элитой и реальными нуждами масс. По оценке Коллонтая, идеи организации управления по принципу иерархических структур в целом “выходят из моды” (с. 185).

Альтернативой иерархически-гегемонистским концепциям выступает модель “управления без государства”. Ее сторонники жестко противопоставляют вертикально-иерархические и горизонтально-сетевые формы организации и управления и считают, что боўльшую часть государственных функций могут взять на себя другие общественные институты и частные организации. Накопленный на сегодняшний день опыт “приватизации” различных государственных и муниципальных функций (в сфере правопорядка, судопроизводства, обеспечения деятельности коммунальных служб, школ, больниц, тюрем и т.д.) предлагается перенести на глобальный уровень. Большие надежды возлагаются также на возрастание роли в политической жизни неправительственных организаций.

Симптомом политического отрезвления Коллонтай считает признание многими западными учеными неизбежности длительного периода сосуществования национальных и глобальных форм управления. Он поддерживает идею “сетевого минимализма” как системы глобального управления экономическими процессами, которая позволит использовать преимущества экономической интеграции без отказа от демократических институтов и либеральных компромиссов.

Общий вывод западных исследователей, к которому присоединяется автор главы, таков: поиски выхода из тупика неолиберальной глобализации только начинаются. В сохранении нынешнего мирохозяйственного порядка, его структур и механизмов регулирования заинтересованы мощные силы - ТНК, международные финансовые центры, международная преступность, некоторые ведущие государства, претендующие на роль гегемонов в мировом сообществе. В какой мере они вынуждены будут отступить под натиском демократических сил и общественных организаций и смогут ли последние разработать реальную программу преобразований, покажет будущее (с. 192).

Проблема управляемости глобального развития подробно рассматривается в главе “Политическая глобализация: институциональные изменения”, автором которой является М.Ильин. В его представлении глобализация есть “процесс становления единого мира — целостного и по своим общим контурам, и по внутренней взаимосвязанности своих взаимопроникающих компонентов” (с. 193). Развертывание глобализации выдвигает на передний план вопросы обеспечения устойчивого (sustainable), т.e. качественного, развития экономических и социальных систем - в отличие от чисто количественной экспансии. В политической сфере данному противопоставлению соответствует различение управления (government ) и управляемости (governance).

По оценке Ильина, глобализация стала продолжением и наиболее отчетливым выражением логики Модерна. Эта логика обретает свой смысл только в условиях актуальной сферичности мира, когда ни одна точка (институция) не может быть постоянным центром, но каждая способна в течение того или иного времени и в том или ином отношении выступать в роли эквивалента такого центра для всех других. В условиях, когда охваченный воздействием Модерна мир, по выражению Т.де Шардена, “свернулся”, выявилось мощнейшее противоречие: необходимо регулировать развитие мира, но нет способов управления. В результате ХХ столетие стало эпохой глобального кризиса (с. 197-198). 
Исследователь подчеркивает необходимость различения между интернационализацией и глобализацией: если первая связана с завершением евроатлантической экспансии в конце XIX в., то вторая — с созданием сетевых структур, предполагающих множественность выходов в глобальную реальность. При этом он акцентирует преобразующую, системно-эволюционную силу глобализации. "Рассматривая политическую модернизацию как 'преодоление’ иерархичности и имперского господства, нельзя не заметить, что иерархические и имперские структуры управления не столько разрушаются, сколько преобразуются”, отмечает он и указывает на преемственность “постиндустриальной” и “индустриальной” систем (с. 199).

Описывая период накопления потенциала развития в терминологии А.Дж.Тойнби, Ильин констатирует, что в формуле “Вызов-и-Ответ” (Challenge-and-Response) богатый творческими импульсами XX в. оказывается скромным “и” - “эволюционной паузой”, когда Вызов уже существует, а Ответ еще не найден (c. 201). Вместе с тем он обращает внимание на то, что с минувшим столетием связаны многие ценнейшие достижения, в частности, опыт включения в политику огромных масс людей и появление внегосударственной публичности (потенциального гражданского общества). И все же, по оценке исследователя, значение XX в. заключается прежде всего в том, что он показал, насколько велико и опасно искушение ускоренного развития, стремления преодолеть “эволюционную паузу” путем реализации проектов контрмодернизации или антимодернизации, и одновременно обнаружил бесперспективность полных и окончательных решений.

В отличие от большинства других авторов монографии, Ильин считает заслуживающими внимания аргументы в пользу лидерства Запада, его способности обеспечить целостность мирового порядка, поскольку именно модернизационный момент, созданный и усиленный евроатлантической (пост)цивилизацией, определил вектор общемирового развития. Однако подобное лидерство, подчеркивает он, должно быть сопряжено с признанием особой эволюционной ответственности наиболее модернизованных политий. Оно должно осуществляться в новых, сетевых формах сотрудничества, а отнюдь не в виде униполярной гегемонии.

Осмысливая проблему суверенитета и насилия, исследователь отмечает, что содержание “эволюционной паузы” (XX в.) составляли не только конфликты, но и попытки найти для мира и свободы собственные, ненасильственные основания. По его мнению, созидательная работа А.Швейцера, М.Ганди, Д.Дольчи, матери Терезы и других миротворцев и социальных реформаторов оказалась более значимой, чем разрушения и насилия, ассоциирующиеся с XX столетием. Ее результатом стало постепенное освоение способов кооперативного взаимодействия с оппонентами как промежуточной ступени к действительно конструктивному ненасилию.

Противоположным решением проблемы насилия в современном мире является терроризм, который трактуется Ильиным как незаконное (несанкционированное системными нормами) применение принуждающего насилия, подрывающее монополию государства на его использование (с. 226-227). Согласно заключению Ильина, одна из важнейших причин терроризма - слабость и кризис самого государства. В глобальном масштабе экономической приватизации сопутствует и приватизация насилия.

В ситуации глобальных экономических, политических и институциональных вызовов государству именно государственный суверенитет выступает в качестве интегратора власти. С точки зрения Ильина, в настоящее время речь идет не о кризисе суверенитета, а о кризисе государств определенного типа - избыточных, перегруженных социальными, экономическими, культурными и прочими не свойственными государству функциями. Глобализация “разгружает” государства, позволяя им вернуться к своей роли механизма поддержания правопорядка в рамках национальных территорий и за их пределами (с. 233). Высказав предположение, что глобализация ведет к формированию не единого мирового гражданского общества, а более сложного и многосоставного комплекса согласованных или согласуемых правовых систем, национальных и цивилизационных стандартов права и прав человека, исследователь отмечает, что такое согласование, а значит - и интеграция реальны лишь при условии сотрудничества и объединения наций-государств как носителей суверенной монополии на легитимное принуждающее насилие (с. 243).

Поднимая вопрос о возможных основаниях всемирного гражданского общества, Ильин не дает на него прямого и однозначного ответа. Следует отметить, что этот автор вообще избегает конкретных рецептов, стараясь изложить проблему комплексно и системно. Рассуждая о категориях суверенитета или об архитектуре мирового политического порядка, о принуждающем насилии или о формах публичности, о моделях гражданского общества или о проблеме устойчивого развития, он остается в рамках научной 
рефлексии, не допуская футурологических спекуляций. Очевидно поэтому важнейшим условием эффективной политической глобализации Ильин считает “широкую публичную дискуссию ученых и политиков о контурах альтернативных ‘архитектур' мирового политического устройства — причем не жесткой, а самодостраивающейся и самонастраивающейся структуры - и о важнейших институциональных узлах, обеспечивающих такое гибкое функционирование” (с. 248).

ВтораЯ Часть монографии посвящена обоснованию глобального характера современных экологических, демографических и социокультурных вызовов и необходимости ответственной консолидации человечества для преодоления негативных последствий антропогенной активности в минувшем XX в.

В главе “Глобальный экологический вызов: теоретический анализ и возможные сценарии” В.Данилов-Данильян и К.Лосев актуализируют проблему глобальных вызовов как вопрос выживания человеческой цивилизации. По убеждению исследователей, все вопросы, которые могут встать перед мировым сообществом в долгосрочной перспективе, находятся в прямой зависимости от решения экологической проблемы.

Систематизировав существующие представления о “глобальной экологии”, авторы приходят к выводу, что в основу обсуждения глобальных экологических проблем должна быть положена теория биотической регуляции окружающей среды. Согласно этой теории, человечество, как и вся окружающая его среда, обязано своим существованием системе живых организмов, биоте, которая создала кислородную атмосферу, высвободила значительную часть океанической воды, сформировала осадочные породы и почву. Очевидно, что возможности любого регулятора, призванного удерживать значения ключевых параметров регулируемой системы в допустимых пределах (интервалах) устойчивости при возмущающих воздействиях, имеют свои границы. Между тем масштабы воздействия на биосферу Земли антропогенного фактора уже превосходят регулирующий потенциал биоты. Несмотря на отсутствие действительно глобальных катастроф, “ползучее” накопление экологических проблем грозит принять необратимый характер (с. 258).

“Антибиосферное” поведение человека чревато нарушением программ его генома: как показывает статистика, доля страдающих генетическими заболеваниями особей среди рождающихся быстро увеличивается. Распад генома человека — глобальная угроза.

Ухудшение состояния окружающей среды под воздействием антропогенных факторов может привести и к серьезным деструкциям экономического характера. Отвлечение все больших средств на локальную защиту от негативных экологических воздействий истощит экономику, замедлит (а то и вовсе прекратит) экономический рост и научно-технический прогресс (с. 264). Требуется радикальная, целенаправленная смена политической, социальной и экономической практики (с. 274). Учитывая такое положение вещей, авторы акцентируют экологический аспект устойчивого развития - воздействие человечества на биосферу не должно превышать пределы ее хозяйственной емкости.

Оценивая проекты создания искусственной окружающей среды и небиотического регулирования биосферы как утопии, Данилов-Данильян и Лосев утверждают: чтобы “выжить”, человечество должно “отступить”, причем не просто прекратить самоубийственный натиск на природу, но и выработать четкую стратегию отступления. По их мнению, на смену исчерпавшей себя рациональности Модерна должна прийти экологическая рациональность как необходимое условие существования человечества (с. 275). Роль экологического авангарда они отводят мировому научному сообществу, за которым последуют экологические движения, массовость которых будет возрастать. Этот процесс способен повлечь за собой и экологизацию политики (с. 275).

Исследователи выделяют три возможных сценария дальнейшего развития экологической ситуации: (1) инерционный, предполагающий сохранение национального эгоизма, господство узкоэкономических критериев в принятии хозяйственных решений и т.п., что будет означать скатывание к апокалиптическому варианту; (2) ультратоталитарный — жесткая мировая диктатура (возможно, двух- или трехполюсная), беспощадная социальная и биологическая евгеника; (3) трансформационный — прорыв к новому мировосприятию, к новой системе ценностей, а быть может, и новой мировой религии, за которым последуют осознанные коллективные действия (с. 281). Пока, по заключению Данилова-Данильяна и Лосева, реализуется первый сценарий, тогда как единственная надежда на выживание человечества переход к третьему. 
О необходимости смены цивилизационной парадигмы, изменения моделей поведения идет речь и в главе “Глобализация и мировое население: социодемографические и этнодемографические сдвиги”, написанной Н.Римашевской. Фокусируя внимание на социо- и этнодемографических трансформациях, исследовательница анализирует динамику численности и изменение структуры мирового населения; обострение проблем бедности, безработицы и социальной поляризации; усиление миграционных процессов; гендерные аспекты глобализации.

С демографической точки зрения, отмечает она, территория Земли может быть поделена на три гигантские зоны: “первый мир” - высокоразвитые государства Запада, составляющие так наз. “золотой миллиард”; “третий мир” - развивающиеся страны; “второй мир” — новые индустриальные страны (Индия, Китай, бывшие республики СССР), по уровню своего развития уступающие мировым лидерам, но опережающие аутсайдеров. Страны “первого мира” уже осуществили переход к новому режиму воспроизводства населения, характеризующемуся низкой рождаемостью и снижением смертности. Социодемографическая ситуация во “втором мире” во многом повторяет некогда пережитый Европой “демографический бум”. Основная часть стран “третьего мира” лишь начинает входить в фазу смены демографической модели, сохраняя сравнительно высокие темпы демографического роста при крайне низком уровне экономического развития, что влечет за собой пауперизацию, люмпенизацию и маргинализацию населения (с. 293-294).

По расчетам экспертов ООН, к 2050 г. численность населения планеты увеличится до 9,4 млрд.чел., к 2100 г. — до 10,4 млрд., а к 2150 г. — до 10,8 млрд. (с. 296). Эксперты прогнозируют также демографическое старение человечества, что неизбежно отразится на экономическом росте, инвестициях, потреблении, рынках труда, пенсиях, налогообложении и т.д. В 1950 г. средняя продолжительность жизни в мире составляла 46 лет, в 2050 г. она достигнет 76 лет. В глобальном масштабе число пожилых людей ежегодно возрастает на $2 \%$, т.е. значительно быстрее, чем численность населения в целом. Вместе с тем в странах “второго” и особенно “третьего мира”, где чрезвычайно велика доля детей и молодежи, обострятся проблемы, связанные с обеспечением образования и занятости. В целом соотношение населения развитых и развивающихся стран будет смещаться в сторону последних, экономически более слабых.

Проанализировав современную ситуацию и прогнозы экспертов, Римашевская приходит к выводу, что в условиях глобальной социальной дифференциации и цивилизационных разрывов, роста нищеты и миграционных потоков, гендерных смещений и гендерных разрывов, экспоненциального изменения всех социодемографических параметров возможность устойчивого компромисса между странами с разным уровнем социально-экономического развития и разным демографическим потенциалом способен обеспечить только переход к новой экологической парадигме и новой глобальной этике. Согласно ее заключению, адекватная новой ситуации модель должна отвечать следующим критериям: (а) осознание необходимости “направляемого” (по В.И.Вернадскому) развития и оценки глобальных последствий предпринимаемых действий; (б) иное отношение к “завтра”, понимание угрозы саморазрушения; (в) отказ от прежней модели межгенерационной передачи культуры; (г) изменение требований к квалификации и образованию, непрерывность обучения; (д) появление новых сообществ, глобальное развитие сетевого образования (с. 289-290).

В главе “Человек перед лицом глобальных процессов” (автор которой - Г.Дилигенский — к сожалению, не дожил до публикации книги) рассматривается воздействие глобализации на сознание и поведение людей. Указывая на неправомерность попыток механически списать на глобализацию все изменения, наблюдаемые сегодня в этой сфере, Дилигенский отмечает, что вектор таких изменений во многом определили процессы, которыми сопровождался переход от Модерна к постмодерну, т.е. от индустриального к постиндустриальному обществу. Вместе с тем он убежден, что глобальное развитие антиинституциональных и антинормативных (или антитрадиционалистских) тенденций нельзя объяснить ни уровнем благосостояния, ни степенью модернизации или “постмодернизации” соответствующих обществ, ни особенностями культуры (с. 334).

По мнению исследователя, воздействие глобализации проявляется прежде всего в том, что она актуализирует свободу индивидуалистического выбора, предполагающую отказ от автоматического следования образцу, заданному социальной средой. Именно эта способность к выбору и создает необходимую психологическую предпосылку отрешения от традиции. Однако и данный феномен, приобретший глобальный характер, обусловлен не только глобализационными процессами. В индустриально развитых, урбанизированных обществах процесс индивидуализации происходит гораздо быстрее и полнее, нежели там, где большое значение сохраняют традиционные социально-групповые 
структуры и соответствующие им типы общественного сознания. При этом индивидуализация может принимать как конструктивные, так и деструктивные формы. Классическим примером деструктивной индивидуализации Дилигенский считает социальную ситуацию в постсоветской России, где распад старых социально-групповых связей не сопровождался утверждением новых.

Обращаясь к истории возникновения и трансформации “общества потребления”, исследователь акцентирует то обстоятельство, что сама динамика этого общества порождает факторы, подрывающие его основы. По мере омассовления, роста возможностей для удовлетворения потребительских запросов возникает ощущение бессмысленности гонки за потреблением, набирает силу стремление к более содержательной деятельности. В результате оказывается, что глобальное измерение приобретают не только ценности общества потребления, но и его идейно-психологическая альтернатива — постматериализм.

Серьезное внимание уделено в главе “глобальной дифференциации” и проблемам идентичности. Согласно заключению автора, в настоящее время можно говорить о складывании особой космополитической идентичности, у которой есть свои центры — так наз. “глобальные города” (крупнейшие города развитых стран, где сосредоточен транснациональный капитал), или “острова глобализации”, и свои носители новые глобальные элиты, непосредственно осуществляющие и обслуживающие глобализацию (финансисты, международные менеджеры, юристы, организаторы транснациональных культурных и информационных коммуникаций и т.д.). К носителями глобализационного сознания он относит также “транснациональную интеллектуальную элиту” (ученые и специалисты, образующие социокультурные общности глобального уровня), а также лидеров и активистов международных неправительственных организаций, в т.ч. антиглобалистских движений, выдвигающих альтернативные проекты глобального развития.

Другим следствием развертывания глобализационных процессов Дилигенский считает обострение проблемы личностной идентичности, которая формируется и утверждается на основе идентичности социальной. В условиях глобализации общественные, макросоциальные отношения людей выходят за рамки национально-государственных общностей, приобретают транснациональный характер, что ведет к размыванию национально-государственной идентичности. Негативно сказываются на идентичности и обусловленные глобализацией деформации в сфере культуры. Именно этим, по мнению Дилигенского, и объясняется активизация национализма и религиозного фундаментализма. Акцентируя национальные чувства и/или религиозные ценности, люди пытаются продемонстрировать целостность своего сознания и поведения, отторжение “чуждых” влияний, прочность связей с традиционной общностью.

Преодолеть противоречие между глобализационными тенденциями и традицией, с точки зрения Дилигенского, можно лишь на основе культурного синтеза. Традиционные ценности сохранят для человека онтологическое значение, определяя его жизненную философию, отношение к себе и к другим людям, при том что в рамках определенного класса отношений и ситуаций (например, в хозяйственной деятельности и материальном потреблении, в сфере образования, развлечений и т.д.) он будет руководствоваться заимствованными нормами и стандартами.

Глобализирующийся мир вовлекает человека во множество взаимодействий и одновременно превращает цели, смысл этих взаимодействий в нечто относительное, ситуационное, преходящее, лишенное того ценностного содержания, которое только и способно формировать устойчивые человеческие общности и устойчивую структуру личности. Эту ситуацию Дилигенский характеризует как кризис человеческой социальности и ее институционального каркаса. Глубина этого кризиса и порождает самые разнообразные, в т.ч. диаметрально противоположные, “стратегии” поведения в условиях глобализации: от космополитизма до крайних форм национализма и религиозного фундаментализма, от активного включения в глобализацию до попыток противостоять ей, замыкаясь в рамках национально-государственных, этнических, религиозных или локальных сообществ (с. 358).

Обоснованию преимуществ социокультурного подхода к процессу глобализации по сравнению с цивилизационным и формационным посвящена глава “Глобальные вызовы и поиски ответа: социокультурный аспект”, подготовленная В.Толстых. Формулируя свою концепцию, автор сразу же дистанцируется от двух крайних исследовательских позиций - демонизации и фетишизации понятия глобализации. По его оценке, глобализация как бы повторяет на новом витке эпоху “осевого времени”, обозначившую начало собственно цивилизованного бытия. Это не “возврат назад”, в архаику безраздельного господства безличного, анонимного существования “доосевой” культуры, а скорее реакция мирового сообщества на кризис созданной им цивилизации, попытка восстановить авторитет и витальную силу идеи 
коллективной ответственности человека и человечества за сохранение целостности и единства мира.

Проанализировав сегодняшнюю ситуацию, исследователь указывает на наличие трех сценариев развития глобального общества: (1) модернизация мирового универсума в рамках логики линейного прогресса, характерной для “Большого Модерна”, т.е. построение глобального сообщества на принципах демократии и либеральных ценностей (рыночной экономики, прав человека и т.д.); (2) постмодернизация, т.е. появление некоего наднационального универсума (мегаобщества) - социально и культурно однородного пространства, объединяющего на чисто прагматической основе светские и посттрадиционные культуры различных частей планеты (эклектическая смесь Востока и Запада, Севера и Юга, выдаваемая за глобальный синтез); (3) формирование многополюсного и многоликого сообщества стран, народов и культур, объединяющихся на основе гуманистических ценностей как техногенного, так и традиционного общества (гуманистический глобализм). Последний проект опирается на идею диалога культур и цивилизаций как альтернативы якобы неизбежному столкновению между ними.

Считая сценарий гуманистического глобализма оптимальным, Толстых связывает его реализацию с “духовной реформацией”. При этом он убежден в продуктивности ставки “на духовную реформацию и новое мышление как предпосылку и условие формирования глобального мира, базирующегося на гуманистических и демократических ценностях”. Такого рода соображения заставляют исследователя весьма оптимистически оценивать перспективы России в глобальном мире - ведь, по его мнению, она всегда представляла свое собственное будущее и будущее мира в глобалистских терминах и понятиях, а поиск объединяющего универсального начала, религиозного или светского, проходит через всю историю отечественной мысли. Кроме того, именно в России возник так наз. космизм - попытка найти нечто “срединное” между западной и восточной мировоззренческими установками.

третьЯ Часть монографии посвящена обсуждению проблем, связанных с поиском Россией своего места в глобализирующемся мире и ее интеграцией в новую систему международной безопасности.

В главе “Самоопределение России в глобализирующемся мире”, написанной В.Медведевым, Ю.Красиным и А.Галкиным, представлен ретроспективный анализ политической истории России и рассмотрены возможные сценарии усиления позиций страны в мировом сообществе. Проанализировав существующие концептуальные подходы к данной проблеме - радикально-либеральный, умеренно-либеральный, реформистско-социалистический (левоцентристский), фундаменталистско-коммунистический и национал-патриотический, — авторы приходят к выводу, что с точки зрения национальных интересов России и ее положения в мире оптимальным вариантом ее политического самоопределения была бы сильная демократия. Вместе с тем изучение перспектив социального самоопределения страны (выбор обществом системы ценностей, определяющих основные направления его развития) приводит авторов к заключению о том, что российская демократия должна иметь социальный уклон.

Следует отметить, что, пытаясь смоделировать будущее России, исследователи отнюдь не склонны идеализировать ее настоящее. Они признают, что сегодня наша страна не имеет объективных оснований (если не считать ядерного оружия и остатков влияния, сохранившихся от Советского Союза) претендовать на роль сверхдержавы. По их мнению, реальные процессы в мировой политике и экономике, где возникают новые очаги “силы”, а наряду с глобализацией развивается регионализация, наиболее адекватно отражает концепция полицентричного мира. В этих условиях “главным резоном” российской политики должно быть не желание ограничить американское влияние, а стремление способствовать созданию системы согласования интересов путем использования положительного опыта ООН и содействия формированию демократического миропорядка.

Учитывая нынешнюю ситуацию, авторы полагают, что в ближайшей перспективе установление у нас прочной демократии маловероятно. Согласно их прогнозу, в стране, скорее всего, утвердится умеренная авторитарная власть, которая возьмет курс на прорыв к социально ориентированной постиндустриальной экономике при одновременном наращивании оборонного потенциала. Это позволит России утвердиться в качестве одной из великих держав мирового сообщества, сыграть свою роль в решении глобальных проблем и формировании более справедливого и разумного мирового порядка.

Завершает книгу глава “Проблемы новой структуры международной безопасности и Россия”, авторы которой - А.Арбатов и А.Пикаев - фокусируют внимание на изменениях в системе международной безопасности и тех императивах, которые в связи с этим встают перед Россией. Исследователи показывают, 
что произошедшие после окончания “холодной войны” политические трансформации и институциональные изменения носили противоречивый характер. На первом этапе (середина 1980-х — середина 1990-х годов) доминировали тенденции к укреплению сложившихся международных институтов и расширению сотрудничества. Эрозия биполярной системы сопровождалась активизацией усилий в области многостороннего международно-правового регулирования. В рамках этого процесса удалось найти взаимоприемлемые решения таких проблем, как объединение Германии и демократизация Восточной Европы, был положен конец гражданским войнам в Камбодже, Мозамбике, Эфиопии, Намибии и т.д. Урегулирование региональных конфликтов стало возможным, в частности, благодаря повышению роли ООН и ряда региональных организаций.

Однако движение в направлении кооперативной многополярности быстро сошло на нет. Этому во многом способствовало изменение соотношения сил между ведущими державами. 1990-е годы, когда США переживали самый длительный и устойчивый экономический подъем в своей истории, Россия и другие постсоветские государства находились в состоянии глубочайшего системного кризиса. В сложном положении пребывали и многие другие потенциальные центры глобального влияния: в Германии замедлились темпы экономического роста, Япония оказалась перед лицом финансового и структурного кризиса, с серьезными финансовыми проблемами столкнулись и восточно-азиатские “тигры” (Южная Корея, Тайвань). Относительное (а в ряде случаев — и абсолютное) ослабление конкурентов спровоцировало Соединенные Штаты на проведение все более агрессивной линии на международной арене.

Последовательно проанализировав политически активные региональные силы, авторы приходят к выводу, что в обозримой перспективе униполярному миру нет реальной альтернативы. В этой ситуации ослабленная и деструктурированная Россия стоит перед сложным выбором. Если сближение с Западом не будет уже в ближайшее время подкреплено экономически и институционально, Кремль может отказаться от своего нынешнего прозападного курса, и российская политика будет переориентирована на Китай. В свою очередь, такой поворот событий способен стать катализатором образования большого Юга - аморфной коалиции государств “третьего мира”, Китая и России. Подобный сценарий представляется Арбатову и Пикаеву далеко не лучшим для России. Считая российско-западный альянс возможным и необходимым, они детально обговаривают условия его формирования (готовность Запада к скорейшей институционализации новых отношений с Россией, учет ее интересов на переговорах о вступлении в ВТО, создание единого экономического пространства между РФ и ЕС; эффективные двусторонние и многосторонние механизмы регулирования взаимодействия России и США на азиатском континенте, прежде всего на Кавказе и в Центральной Азии). Вместе с тем вопрос о том, какая стратегия была бы оптимальной для самой России, к сожалению, оставлен ими без ответа.

$* * *$

Завершая обзор этого безусловно новаторского труда Горбачев-фонда, следует отметить, что в нем сделан не только важный шаг в осмыслении глобализации как феномена, накладывающего глубокий отпечаток на все стороны существования мирового сообщества, но и положено начало фундированному преодолению чисто эйфорического отношения к той модели глобального развития, которая реализуется в последние годы. Последовательно проводимая авторами книги мысль о необходимости разведения объективных процессов, разворачивающихся в современном мире, и эгоистической политики неолиберального глобализма, не решающей, а скорее порождающей трудные и даже опасные проблемы, позволяет по-новому взглянуть на происходящее и побуждает к дальнейшим исследованиям.

[1]Грани глобализации. Трудные вопросы современного развития. М.: Альпина паблишер, 2003. — 592 с. 